\title{
Characterization of sodium alginate extracted from brown seaweeds growing on Veraval coast, Gujarat
}

\author{
Kiran Dangar, Vaishali Varsani \& Suhas Vyas* \\ Department of Life Sciences, Bhakta Kavi Narsinh Mehta University, Junagadh 362 001, Gujarat, India \\ *Email:vsuhas.13@gmail.com
}

\section{ARTICLE HISTORY}

Received: 27 August2020

Accepted: 03 November 2020

Published: 01 January 2021

\section{KEYWORDS}

Brown seaweeds

Veraval

Natural resources

Extraction

\begin{abstract}
Marine environment is a major potential source of functional materials, including polysaccharides, vitamins, enzymes, oils, antioxidants and peptides. All these materials are extracted from different marine living organisms including microbes, plants and animals. Among these seaweeds or marine macroalgae are one of the important sources and they are a part of staple diet from time immemorial in the orient as they are nutritionally rich materials. Those species that adapted to these pressures will expand their living boundaries and higher potential of row material availability in industry like pharmaceutical market, textile, fertilizer and for animal and human consumption. The present study concerns about the specific brown seaweeds, which is suitable material for alginate and growing abundantly at seacoast of Gujarat. Out of many species of seaweeds growing on the coastline of Veraval, four species viz., Sargassum tenerrimum, Dictyota dichotoma, Spathoglossum asperum, lyengaria stellata were selected for alginate extraction. The focus of this study is to utilize natural resources as alternatives and sustainability of human health to use sodium alginate as novel polymer and which is also biodegradable. It may be associated to other biologically active molecules and has a wide range of physicochemical and biochemical properties. Because of amazing properties, alginate and its salts are used in drug delivery system.
\end{abstract}

\section{Introduction}

Seaweeds neither need fertile and productive land nor freshwater to flourish in oceans. They are attributed as primary producers, as they productively absorb inorganic compounds from the seawater and transform them to macronutrients, namely lipids, carbohydrates and proteins. Present scenario of research the scientist has been given more attention to seaweeds biomass and especially the brown seaweeds, which has a major source of bioactive polysaccharides such as fucoidan, laminaran, alginates and mannitol have been studied because of their productiveness as anticoagulant, anticancer, antitumor, antithrombotic, anti-inflammatory, contraceptive and antiviral agent (1). Alginic acid is a polysaccharide composed of uronic acids and obtained in the universe as one constituent of brown seaweeds and as capsular polysaccharides in soil born bacteria. Alginate is the most abundant marine biopolymer and occurs in the intracellular mucilage and algal cell wall (2). The utilization of alginate is based on three main properties. The first is their potentiality to dissolve in water and thicken the resulting solution. The second is to form gels when a calcium salt is added to a solution of sodium alginate in water (3). The third property of alginate is the ability to form films of sodium or calcium alginate and fibers of calcium alginate (4).

\section{Materials and Methods}

\section{Study area:}

Veraval chopati is located at $20.9^{\circ} \mathrm{N}$ Latitude and $70.37^{\circ} \mathrm{E}$ Longitude Gujarat coastline of Veraval is about $3.5 \mathrm{~km}$ long with rocky substratum, slightly muddy with abundance of coral species. At the intertidal zone of Veraval has great diversity of

(c) Dangar et al (2021). This is an open-access article distributed under the terms of the Creative Commons Attribution License, which permits unrestricted use, distribution and reproduction in any medium, provided the original author and source are credited (https://creativecommons.org/licenses/by/4.0/).

To cite this article: Dangar K, Varsani V, Vyas S. Characterization of sodium alginate extracted from brown seaweeds growing on Veraval coast, Gujarat. Plant Science Today. 2021;8(1):45-48. https://doi.org/10.14719/pst.2021.8.1.932 
seaweeds, there are four species of brown seaweeds, which were collected from the study area and used as source of alginate.

\section{Collection of seaweeds:}

Four species of brown seaweeds (Sargassum tenerrimum, Dictyota dichotoma, Spathoglossum asperum and Iyengaria stellata) were collected from Veraval coastal area during (February / 2018). The collected seaweeds species were washed, identified taxonomically and classified according to seaweeds of India [4]. Selected species gradually treated with acid $(\mathrm{HCl})$, alkali $(\mathrm{NaOH})$ and formaldehyde. The species were oven dried and converted into fine powder and stored for further use.

\section{Extraction of sodium alginate:}

The method of extraction of sodium alginate that had been according to mentioned by Rinta Kusumawati [5]. In the current study, we have slightly modified the method, in which $100 \mathrm{gm}$ sample (milled seaweeds) weighted and soaked in $4 \% \mathrm{CaCl}_{2}$ taken in air tight bottle for $2 \mathrm{hr}$, after $2 \mathrm{hr}$ filtered out and residue transfer for acid treatment of $5 \% \mathrm{HCl}$ for 20 min. In the third step, treatment with $40 \%$ formaldehyde for one $\mathrm{hr}$ and the sample was then washed with distilled water for $20 \mathrm{~min}$ and added a 1 $\mu \mathrm{g}$ of $\mathrm{MgCO}_{3}$ to break down cell wall. Final residue was extracted with $80 \%$ iso-propane for overnight. The precipitate was washed with acetone and filtrate was bleached with $1 \%, 1.5 \%$ and $2 \%$ sodium hypo chloride. The solution was evaporated and dried overnight at $40{ }^{\circ} \mathrm{C}$ in hot air oven.

\section{Physicochemical property of sodium alginate pH}

For estimation of $\mathrm{pH} 1 \mathrm{gm}$ of product (sodium alginate) was dissolved in $100 \mathrm{ml}$ of distilled water (5). The digital $\mathrm{pH}$ meter was used to determine $\mathrm{pH}$ of sodium alginate (Digital pH meter).

\section{Moisture content}

The mass of the sodium alginate on heating at $45{ }^{\circ} \mathrm{C}$ under the specified operating conditions (4).

\section{Ash content}

The ash content was obtained by gravimetric method by heating the sample in the crucible till the sample is converted into ash (6).

\section{Solubility}

Different organic solvents and acids are used to determine the solubility of sodium alginate. $0.1 \mathrm{gm}$ of sodium alginate was dissolved in $1 \mathrm{ml}$ of individual solvents such as water, acetone, ether, chloroform and acids such as hydrochloric acid $(\mathrm{HCl})$ and sulphuric acid $\left(\mathrm{H}_{2} \mathrm{SO}_{4}\right)$.

\section{Determination of purity of sodium alginate (phytochemical analysis)}

To determine the purity of sodium alginate, tests for alkaloids, carbohydrates, flavonoids, steroids, phlobatannins, glycosides, terpins, saponins, tannins and phenols were carried out using standard methodologies (7). Organoleptic evaluation is to find out the colour, odour, taste and texture of extracted sodium alginate.

\section{Biochemical constituents of sodium alginate Protein}

The protein presence in sodium alginate was determined by the biurette method. Protein was calculated by using BSA as standard and expressed as $\mathrm{mg} / \mathrm{gm}$ protein (8).

\section{Estimation of carbohydrate}

Total carbohydrate contain in alginate was carried out by anthrone method by referring to standard DGlucose and results have been expressed as mg/gm sugar (9).

\section{Results and Discussion}

The different seaweed species showed variation in the yield of alginate after bleaching with $1-2 \%$ sodium hypo chloride showed the highest alginate extracted at $1.5 \%$ sodium hypo chloride solution from Dictyota dichotoma species (19.43\%) and with the increasing concentration of hypo chloride solution the yield of sodium alginate was decrease. Usually the sodium alginate content of various seaweeds is varied much. Sargassum tenerrimum had 16.32\% alginate content at $2 \%$ sodium hypo chloride, Spathoglossum asperum had $17.45 \%$ at $1.5 \%$ concentration and Iyengaria stellata had $16.63 \%$ at $1 \%$ sodium hypo chloride. Variation being depended on the alginate extraction method and also the variation in the species of seaweeds (Table 1).

Table 1. Yield of sodium alginate which expressed as weight percentage with different concentration of alkali solution.

\begin{tabular}{|c|c|c|c|}
\hline Sl. No. & Name of species & $\begin{array}{c}\text { Yield of alginate } \\
\text { (\%) }\end{array}$ & $\begin{array}{l}\text { Concentration of } \\
\text { sodium } \\
\text { hypochloride (\%) }\end{array}$ \\
\hline \multirow{3}{*}{1} & \multirow{3}{*}{$\begin{array}{l}\text { Sargassum } \\
\text { tenerrimum }\end{array}$} & 15.00 & 1 \\
\hline & & 15.12 & 1.5 \\
\hline & & 16.32 & 2 \\
\hline \multirow{3}{*}{2} & \multirow{3}{*}{ Dictyota dichotoma } & 19.39 & 1 \\
\hline & & 19.43 & 1.5 \\
\hline & & 18.73 & 2 \\
\hline \multirow{5}{*}{3} & \multirow{5}{*}{$\begin{array}{l}\text { Spathoglossum } \\
\text { asperum }\end{array}$} & 17.23 & 1 \\
\hline & & 17.43 & 1.5 \\
\hline & & 17.45 & 2 \\
\hline & & 17.64 & 1.5 \\
\hline & & 15.31 & 2 \\
\hline \multirow{3}{*}{4} & \multirow{3}{*}{ Iyengaria stellata } & 16.63 & 1 \\
\hline & & 16.46 & 1.5 \\
\hline & & 15.00 & 2 \\
\hline
\end{tabular}

\section{Yield of sodium alginate}

The phytochemical analysis was carried out in the present study to determine the purity of the extracted sodium alginate. This result showed that the extracted sodium alginate of selective seaweed species pure form and it has no trace of any phytochemicals, but the only element carbohydrate and its derivative saponins were present, which confirmed its better purity (Table 2). 
Table 2. Determination of purity of sodium alginate (phytochemical analysis)

\begin{tabular}{clcccc}
\hline $\begin{array}{c}\text { Sl. } \\
\text { No. }\end{array}$ & Tests & $\begin{array}{c}\text { S. } \\
\text { tenerrium }\end{array}$ & $\begin{array}{c}\text { D. } \\
\text { dichotoma }\end{array}$ & $\begin{array}{c}\text { S. } \\
\text { asperum }\end{array}$ & $\begin{array}{c}\text { I. } \\
\text { stellata }\end{array}$ \\
\hline 1 & Carbohydrate & + & +++ & ++ & +++ \\
\hline 2 & Alkaloids & - & - & - & - \\
\hline 3 & flavonoids & - & - & - & - \\
\hline 4 & Steroids & - & - & - & - \\
\hline 5 & Phlobatannins & - & - & - & - \\
\hline 6 & Glycosides & - & - & - & - \\
\hline 7 & Terpins & - & - & - & - \\
\hline 8 & Saponins & ++ & +++ & + & + \\
\hline 9 & Tannins & - & - & - & - \\
\hline $\begin{array}{l}(+) \\
\text { very }\end{array}$ & posigh content
\end{tabular}

\section{Organoleptic characters evaluation}

The organoleptic characters showed that all the seaweeds were noted to be odourless, whereas, $S$. tenerrimum was found to be salty in taste and rest of the other seaweeds were tasteless. Characters of sodium alginate from $S$. tenerrimum were noted to be yellowish grey, odourless, salty taste and was observed to be powdery in appearance. Sodium alginate from $D$. dichotoma were noted to be white, odourless, tasteless and granular in texture. Characteristics of sodium alginate from I. stellata were having characteristics of brownish black, tasteless, odourless and granular in texture (Table 3).

Table 3. Organoleptic characters evaluation of sodium alginate

\begin{tabular}{|c|c|c|c|c|c|}
\hline $\begin{array}{l}\text { Sl. } \\
\text { No. }\end{array}$ & Characters & $\begin{array}{c}S . \\
\text { tenerrimum } \\
\end{array}$ & $\begin{array}{c}\text { D. } \\
\text { dichotoma }\end{array}$ & $\begin{array}{c}S . \\
\text { asperum }\end{array}$ & $\begin{array}{c}\text { I. } \\
\text { stellata }\end{array}$ \\
\hline 1 & Colour & $\begin{array}{c}\text { Yellowish } \\
\text { grey }\end{array}$ & White & $\begin{array}{l}\text { Greyish } \\
\text { green }\end{array}$ & $\begin{array}{c}\text { Brownish } \\
\text { black }\end{array}$ \\
\hline 2 & Taste & Salty & Tasteless & Tasteless & Tasteless \\
\hline 3 & Odour & $\begin{array}{l}\text { seaweed } \\
\text { order }\end{array}$ & Odourless & Odourless & $\begin{array}{l}\text { seaweed } \\
\text { odour }\end{array}$ \\
\hline 4 & Texture & Powder & Granular & $\begin{array}{l}\text { Smooth } \\
\text { powdery }\end{array}$ & Granular \\
\hline
\end{tabular}

\section{Estimation of $\mathrm{pH}$ and moisture}

The $\mathrm{pH}$ of $1 \%$ sodium alginate of selective species range 9.6-8.2. Maximum $\mathrm{pH}$ observed was in $S$. tenerrimum, whereas in I. stellata was noted to be minimum. The moisture content of sodium alginate observed ranged 16.52-11.87\% maximum in $I$. stellata and minimum in S. asperum. Other than that, the $S$. tenerrimum and $D$. dichotoma had observed $12.65 \%$ and $14.72 \%$ respectively (Table 4 ).

\section{Solubility}

The solubility of sodium alginate showed that it was readily soluble in hydrochloric acid and sulphuric acid however, it was insoluble in all the other trailed solvents such as distilled water, ethanol, methanol, acetone, ether and chloroform (Table 5).

\section{Ash content}

The result of water-soluble ash content in Sargassum tenerrimum was noted to be higher $(14.40 \%)$ than the other species. Water soluble ash content in Spathoglossum asperum (11.31\%) and Iyengaria stellata (11.52\%) was having marginal variations.
Table 4. Estimation of $\mathrm{pH}$ value of sodium alginate

\begin{tabular}{clcc}
\hline Sl. No. & Name of species & Value of $\mathbf{p H}$ & $\begin{array}{c}\text { Moisture } \\
\mathbf{( \% )}\end{array}$ \\
\hline 1 & Sargassum tenerrimum & 9.6 & 12.65 \\
\hline 2 & Dictyota dichotoma & 8.9 & 14.72 \\
\hline 3 & Spathoglossum asperum & 9.5 & 11.87 \\
\hline 4 & Iyengaria stellata & 8.8 & 16.52 \\
\hline
\end{tabular}

Table 5. Ash content of sodium alginate

\begin{tabular}{cccc}
\hline $\begin{array}{c}\text { Sl. } \\
\text { No. }\end{array}$ & $\begin{array}{c}\text { Name of } \\
\text { species }\end{array}$ & $\begin{array}{c}\text { Water soluble Ash } \\
\text { content }\end{array}$ & $\begin{array}{c}\text { Acid insoluble ash } \\
\text { content }\end{array}$ \\
\hline 1 & S. tenerrimum & $14.40 \%$ & $3.63 \%$ \\
\hline 2 & D. dichotoma & $10.86 \%$ & $5.71 \%$ \\
\hline 3 & S. asperum & $11.31 \%$ & $2.06 \%$ \\
\hline 4 & I. stellata & $11.52 \%$ & $3.85 \%$ \\
\hline
\end{tabular}

Species of Dictyota was noted to be lower in ash content (10.86\%) compared to that of other seaweeds. Unlike to water soluble ash content, the acid soluble ash content was found to be having a noticeable range in all the seaweed species. The maximum acid soluble ash was observed in $D$. dichotoma (5.71\%) and minimum acid soluble ash content was noted in S. asperum (2.06\%) (Table 5).

\section{Biochemical properties}

\section{Carbohydrates}

Important biomolecules found to be present in the seaweeds, which creates their biological importance. Results of carbohydrate as a major source of energy and nutrition in sodium alginate was recorded to be in the range of $48.09-32.76 \mu \mathrm{g} / \mathrm{ml}$. Maximum concentration of carbohydrate was noted in $S$. tenerrimum and minimum in S. asperum. The values of protein content were interestingly found to be low than that of carbohydrates in different species of seaweeds. Range of protein content was observed to be 10.33 (S. asperum) to $29 \mu \mathrm{g} / \mathrm{ml}$ ( $D$. dichotoma) (Table 6).

Table 6. Mean value of triplicate observation Carbohydrates estimation from sodium alginate

\begin{tabular}{rlcc}
\hline $\begin{array}{l}\text { Sl. } \\
\text { No. }\end{array}$ & Name of species & Carbohydrate $\boldsymbol{\mu g} / \mathbf{m l}$ & $\begin{array}{c}\text { Protein } \\
\boldsymbol{\mu g} / \mathbf{m l}\end{array}$ \\
\hline 1 & S. tenerrimum & 48.09 & 25.60 \\
\hline 2 & D. dichotoma & 43.98 & 10.33 \\
\hline 3 & S. asperum & 32.76 & 29.00 \\
\hline 4 & I. stellata & 41.74 & 13.3 \\
\hline
\end{tabular}

\section{Conclusion}

The major purpose of the study on seaweeds is for their utility in many industrial applications. Many countries utilise these seaweeds for extraction of valuable compounds used in companies of cosmetics, paints, food, medicine etc. From the current study, it can be derived that many biologically active compounds from the phytochemical study of seaweed can be helpful in the industries. It can be concluded that there is remarkable variation in the concentration of two important biomolecules i.e. carbohydrates and protein. All the seaweed species taken for the study showed variation in the production of sodium alginate and hence all these species are of having good potential as economical 
value. Seaweeds protein is used as an alternative source of dietary protein. The study of their physicochemical properties and biochemical composition discloses their appropriateness to be a beneficial source of food for human utilisation and consumption. There are several seaweeds with economic potential throughout the coastal belt of Gujarat coast. In the present study, it is indicated that all the four different seaweeds would be a good source of raw materials of sodium alginate. The exploitation of seaweed and other marine resources should be sustainable and needed to be balanced with the establishment of their growth. From the data of the present study, we can strongly reveal that seaweed culture should be extensively promoted for sustainable development in the coastal region of the country. Marine agronomy is to be developed and enhanced for the mass production of such species of seaweed for finding new natural resources.

\section{Acknowledgements}

All authors acknowledge Bhakta Kavi Narsinh Mehta University, Junagadh for providing the infrastructure for conducting the experiments in the laboratory.

\section{Authors' contributions}

KD performed the practical and analytical portion of the experiments conducted during the study. VV carried out the collection of seaweed species. SV interpreted the data obtained and drafted the manuscript and coordination. All authors read and approved the final manuscript.

\section{Conflict of interests}

Authors do not have any conflict of interests to declare.

\section{References}

1. Rodriguez-Jasso RM, Mussatto SI, Pastrana L, Aguilar CN, Teixeira JA. Microwave-assisted extraction of sulfated polysaccharides (fucoidan) from brown seaweed. Carbohydrate Polymers. 2011 Aug 30;86(3):1137-44. https://doi.org/10.1016/j.carbpol.2011.06.006

2. Niekraszewicz B, Niekraszewicz A. The structure of alginate, chitin and chitosan fibres. In: Handbook of Textile Fibre Structure 2009 Jan 1 (pp. 266-304). Woodhead Publishing. https://doi.org/10.1533/9781845697310.2.266

3. Touloupakis E, Ghanotakis DF. Nutraceutical use of garlic sulfur-containing compounds. In: Bio-Farms for Nutraceuticals 2010 (pp. 110-121). Springer, Boston, MA https://link.springer.com/chapter/10.1007/978-1-4419-7347-4_9

4. Jha B, Reddy CR, Thakur MC, Rao MU. Seaweeds of India: the diversity and distribution of seaweeds of Gujarat coast Springer Science \& Business Media; 2009 Jun 23. https://doi.org/10.10071978-90-481-2488-6

5. Kusumawati R, Basmal J, Utomo BB. Physicochemical characteristics of sodium alginate extracted from Turbinaria sp. and Sargassum sp. Squalen Bulletin of Marine and Fisheries Postharvest and Biotechnology. 2018 Aug 31;13(2):7984. http://dx.doi.org/10.15578/squalen.v13i2.297

6. Mollah MZ, Khan MA. Mechanical properties development of sodium alginate films with additives by UV-radiation processing. Journal of Applied Polymer Science. 2012 Apr 5;124(1):275-81._https://doi.org/10.1002/app.34381

7. Holdt SL, Kraan S. Bioactive compounds in seaweed: functional food applications and legislation. Journal of Applied Phycology. $2011 \quad$ Jun 1;23(3):543-97. https://doi.org/10.1007/s10811-010-9632-5

8. Kannan M, Pushparaj A, Dheeba B, Nageshwari K, Kannan K. Phytochemical screening and antioxidant activity of marine algae Gracilaria corticata and Spirulina platensis. Journal of Chemical and Pharmaceutical Research. 2014;6(11):312-18. https://pdfs.semanticscholar.org/1735/b930d8efa4997caa86a77 cb64c950dfcef35.pdf

9. Mushollaeni W. The physicochemical characteristics of sodium alginate from Indonesian brown seaweeds. African Journal of Food Science. 2011 Jun 30;5(6):349-52. https://doi.org/10.5897/AJFS.9000296

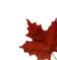

